\title{
Correction: Development of an optimized AAV2/5 gene therapy vector for Leber congenital amaurosis owing to defects in RPE65
}

\author{
A. Georgiadis ${ }^{1} \cdot$ Y. Duran ${ }^{1} \cdot$ J. Ribeiro ${ }^{1} \cdot$ L. Abelleira-Hervas ${ }^{1} \cdot$ S. J. Robbie ${ }^{1} \cdot$ B. Sünkel-Laing ${ }^{1} \cdot$ S. Fourali ${ }^{1}$ \\ A. Gonzalez-Cordero ${ }^{1}$ E. Cristante ${ }^{1}$ - M. Michaelides ${ }^{1,2}$ J. W. B. Bainbridge ${ }^{1,2}$ - A. J. Smith ${ }^{1} \cdot$ R. R. Ali ${ }^{1,2}$
}

Published online: 25 July 2018

(c) The Author(s) 2018. This article is published with open access

Correction to: Gene Therapy https://doi.org/10.1038/gt. 2016.66, published online 22 September 2016

This Article was originally published under a CC BYNC-SA 4.0 license, but has now been made available under a CC BY 4.0 license. The PDF and HTML versions of the Article have been modified accordingly.

R. R. Ali

r.ali@ucl.ac.uk

1 Department of Genetics, UCL Institute of Ophthalmology, London EC1V 9EL, UK

2 NIHR Biomedical Research Centre at Moorfields Eye Hospital, London EC1V 2PD, UK
Open Access This article is licensed under a Creative Commons Attribution 4.0 International License, which permits use, sharing, adaptation, distribution and reproduction in any medium or format, as long as you give appropriate credit to the original author(s) and the source, provide a link to the Creative Commons license, and indicate if changes were made. The images or other third party material in this article are included in the article's Creative Commons license, unless indicated otherwise in a credit line to the material. If material is not included in the article's Creative Commons license and your intended use is not permitted by statutory regulation or exceeds the permitted use, you will need to obtain permission directly from the copyright holder. To view a copy of this license, visit http://creativecommons. org/licenses/by/4.0/. 